\title{
SOLAR CHARGE CONTROLLER FOR DOMESTIC APPLICATION
}

\author{
Mayur N Mallya, Manasa P, Sameeksh M Shetty, Shamu M \\ Undergraduate students \\ Department of Electrical and Electronics Engineering \\ BMS college of Engineering, \\ Bangalore, Karnataka, India \\ Ms. Soniya Agrawal \\ Assistant Professor, \\ Department of Electrical and Electronics Engineering \\ BMS college of Engineering, \\ Bangalore, Karnataka, India
}

\begin{abstract}
In this paper, a solar charge controller with Maximum Power Point Tracking is designed and implemented using Matlab Simulink. There is also an output inverter integrated with the system to obtain a single phase AC output to power the home appliances. For the maximum power point tracking two methods, the Perturb and Observe (P\&O) and Incremental Conductance (INC) algorithms are implemented and their performance is analysed. With the changing irradiance, the MPP is tracked effectively and a regulated DC voltage is obtained using Buck-Boost converter, which is suitable for the selected pulse width modulation (PWM) inverter. Mathematical modelling of the same is performed, establishing the relation between various mathematical equations and estimating quantitative behavior of the physical system.
\end{abstract}

Keywords - Solar Photovoltaic (PV) System, MPPT, P\&O Algorithm, INC Algorithm, DC-DC Buck Boost Converter, PWM inverter, Charge Controller

\section{INTRODUCTION}

Developing countries like India rely on conventional sources for their energy demand. In recent days it can be seen that the prices of these sources are increasing rapidly. This could cause energy scarcity and deteriorate the lifestyle of its citizens. Due to these reasons we need to switch to much cheaper and efficient sources of energy. There are many sources of non conventional energy sources and one of them being solar energy which is free of cost and abundantly available. This can be harnessed easily with the help of solar panels and few protection devices.

This source has numerous advantages. It can either be used on grid or off-grid. The remote places like villages or places with less grid connectivity can be off grid. The places with good grid connectivity can use this as an on-grid system and supply the excess energy generated to the grid.

The paper gives an overview about a solar charge controller which comprises a solar panel, MPPT algorithm, Buck-Boost converter and inverter.

The looms solar 180W panel has been considered here for experimentation. Here two types of MPPT algorithms are used. One being $\mathrm{P} \& \mathrm{O}$ [1] and other being the INC algorithm, while there are various algorithms available [2]. The buck-boost converter with a closed loop control provides a constant DC voltage to the inverter to obtain a single phase AC voltage. The inverter uses PWM technique. MPPT solar charge controllers are more effective and widely used than PWM controllers [3][6]. The functional blocks of the system will be explained in further sections.

II. SYSTEM DESIGN

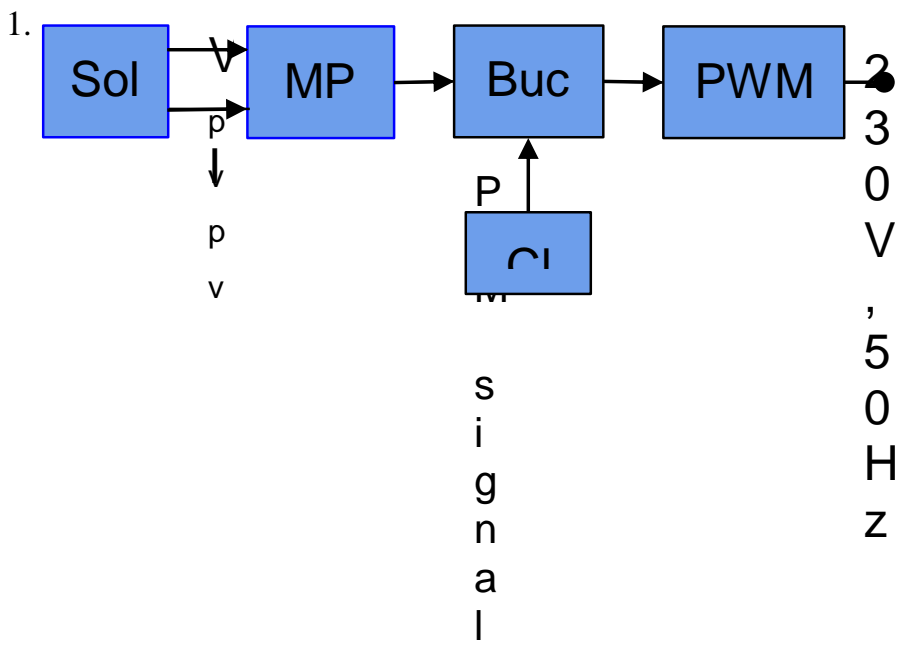

Fig. 1. Block diagram of the MPPT charge controller 


\section{International Journal of Engineering Applied Sciences and Technology, 2021 \\ Vol. 6, Issue 1, ISSN No. 2455-2143, Pages 325-330 \\ Published Online May 2021 in IJEAST (http://www.ijeast.com)}

A.

Solar Panel

A photovoltaic cell is a semiconductor device made up of crystalline silicon that converts solar energy into electrical energy by the principle of photovoltaic effect. Such solar cells are arranged in series and/or parallel in order to meet the required voltage and current requirements and form the PV module. The below table lists the electrical specifications of the solar panel measured at Standard Test Conditions (STC) i.e. $1000 \mathrm{~W} / \mathrm{m}^{2}$ irradiance and $25^{\circ} \mathrm{C}$ temperature.

Table - 1 PV panel electrical parameters at STC

\begin{tabular}{|l|c|}
\hline \multicolumn{1}{|c|}{ Parameters } & Rating \\
\hline Cell Configuration(Nos) & 36 \\
\hline Maximum Power( $\left.\mathbf{P}_{\text {max }}\right)$ & $180 \mathrm{~W}$ \\
\hline $\begin{array}{l}\text { Voltage at Maximum at } \\
\text { PowerPoint }\left(\mathbf{V}_{\mathrm{m}}\right)\end{array}$ & $19.95 \mathrm{~V}$ \\
\hline Current at maximum powerpoint $\left(\mathbf{I}_{\mathrm{m}}\right)$ & $9.03 \mathrm{~A}$ \\
\hline Open circuit voltage $\left(\mathbf{V}_{\text {oc }}\right)$ & $23.26 \mathrm{~V}$ \\
\hline Short circuit current $\left(\mathbf{I}_{\text {sc }}\right)$ & $9.53 \mathrm{~A}$ \\
\hline
\end{tabular}

The simulink model of the panel was designed with help of the above shown parameters [7]. The design equations used for mathematical model [8][9] are given below:

1) Module photo-current Iph:

$I p h=[I s c+K i(T-298)] \times \operatorname{Ir} / 1000$

Where, Isc $=$ short circuit current

$\mathrm{K}_{\mathrm{i}}=$ Short circuit current of the cell at $25^{\circ} \mathrm{C}, 1000 \mathrm{~W} / \mathrm{m}^{2}$

$\mathrm{T}=$ operating Temperature

Ir $=$ solar irradiation

2) Module reverse saturation current Irs:

$I r S=I s c /\left[e^{(q . V o c / N s . k . N . T)}-1\right]$

Where, $\mathrm{q}=$ electron charge $=1.6 \times 10^{-19} \mathrm{C}$

Voc $=$ open circuit voltage

$\mathrm{Ns}=$ no. of cells connected in series

3) Module saturation current Io:

$I o=\operatorname{Irs}[T / T r] \quad{ }^{3} e^{[q \times E g o / n k(1 / T-1 / T r)]}$

Where, $\operatorname{Tr}=$ Nominal Temperature

Ego $=$ band gap energy of semiconductor $=1.1 \mathrm{eV}$

$\mathrm{n}=$ ideality factor

$\mathrm{k}=$ Boltzmann Constant $=1.38 \times 10^{-23} \mathrm{~J} / \mathrm{K}$

4) The current output of PV module:

The output current of the panel is given by the equation,
$I=N p \times I p h-N p \times I o \times\left[e^{(V / N S+I \times R s / N p) / n . V t}-\right.$

1] - Ish

$V t=k \times T / q$

$I s h=(V \times N p / N s+I \times R s) / R s h$

Where, $\mathrm{Vt}=$ Diode terminal voltage

$\mathrm{Np}=$ No. of PV Modules connected in parallel

The output of the solar panel is fed to the MPPT controller.

\section{B. MPPT Controller -}

MPPT controller is used to track and maintain the operating point near the maximum power point. The maximum power varies with solar radiation, cell temperature and ambient temperature. The MPPT algorithm is implemented using a Boost Converter whose circuit components are designed using the following equations. This logic can be implemented using a microcontroller in hardware projects [4][5].

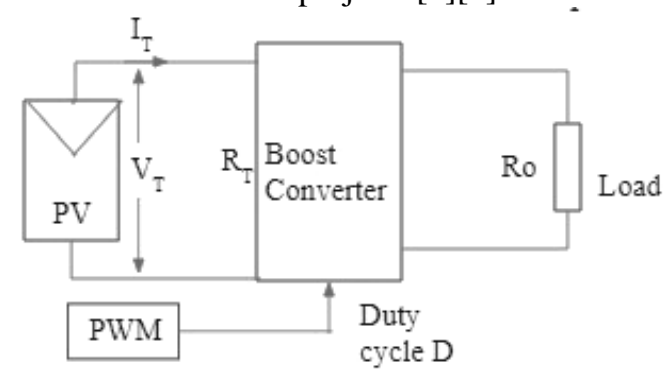

Fig. 2. MPPT with boost converter

For $1000 \mathrm{~W} / \mathrm{m}^{2}$, the panel voltage and current are $\mathrm{V}_{\mathrm{T}}=19.95 \mathrm{~V}$, $\mathrm{I}_{\mathrm{T}}=9.03 \mathrm{~A}$ respectively. $\mathrm{R}_{\mathrm{T}}=2.2093 \Omega$. Let load resistor $\mathrm{R}_{\mathrm{o}}=$ $10 \Omega$, switching frequency $\mathrm{f}_{\mathrm{sw}}=50 \mathrm{KHz}$

For the Boost converter,

$R_{o}=R_{T} /(1-D)^{2}$

Therefore, $\mathrm{D}=0.5299$

Boost converter output voltage is given by,

$V_{o}=V_{T} /(1-D)$

Hence, $\mathrm{Vo}=42.437 \mathrm{~V}$

Current through the inductor is given by,

$I_{L}=V_{T} /(1-D)^{2} R$

Hence, $\mathrm{I}_{\mathrm{L}}=9.0274 \mathrm{~A}$

Considering the ripple in output voltage and inductor current to be $0.1 \%$,

$\Delta i_{L}=0.1 \% * I_{L}$

Hence $\Delta \mathrm{i}_{\mathrm{L}}=9.0274 \mathrm{~mA}$

Inductor of the Boost converter is given by,

$L=V_{T} D T_{s} / \Delta i_{L}$

Hence, $\mathrm{L}=23.42 \mathrm{mH}$ 


\section{International Journal of Engineering Applied Sciences and Technology, 2021 \\ Vol. 6, Issue 1, ISSN No. 2455-2143, Pages 325-330 \\ Published Online May 2021 in IJEAST (http://www.ijeast.com)}

Capacitor of the converter is given by,

$C=D T_{s} / R\left(\Delta V_{o} / V_{o}\right)$

Hence, obtain, $\mathrm{C}=10.6 \mathrm{mF}$.

The MPPT algorithms that are employed are Perturbation and Observation ( $\mathrm{P} \& \mathrm{O}$ ) and Incremental Conductance (INC) techniques. The flowchart of these algorithms are shown below in Fig. 3 and Fig. 4 respectively.



Fig. 3. Flowchart P \& O Algorithm



Fig. 4. Flowchart INC Algorithm.

\section{DC-DC Converter -}



Fig. 5. Buck-Boost converter

The buck boost converter acts as both buck and boost converters depending on duty ratio. It acts as a buck from duty ratio of 0 to 0.5 and acts as a boost converter from 0.5 to 1 . The output of the converter is inverted by $90^{\circ}$. A closed loop control [10] is implemented in order to keep the output constant with varying input. The design calculations of the buck-boost converter are as follows:

Let the switching frequency be $\mathrm{f}_{\mathrm{sw}}=100 \mathrm{kHz}$, load resistor $\mathrm{R}_{\mathrm{o}, \min }=1 \Omega$, percentage ripple of output voltage be $0.01 \%$

For the minimum output voltage from MPPT i.e. $\mathrm{V}_{\text {in,min }}=10 \mathrm{~V}$, $\mathrm{V}_{\mathrm{o}}=12.6 \mathrm{~V}$

The output to input ratio of buck-boost converter is,

Vo/Vin $=D /(1-D)$

Therefore, $\mathrm{D}_{\mathrm{Vin}=10 \mathrm{~V}}=12.6 /(12.6+10)=0.5575$

To calculate the value of the inductor, we use,

$L=1.25 L_{\min }$

$\operatorname{Lmin}=(1-D)^{2} R / 2 f$

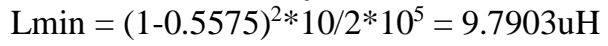

Therefore, $\mathrm{L}=1.25 * 9.7903 \mathrm{uH}=14.685 \mathrm{uH}$

The capacitor value is given by,

$C=V_{\text {in }} * D^{2} * T_{S} /\left(\Delta V_{o} *(1-D) * R_{o}\right)$

Hence we get $\mathrm{C}=55.8 \mathrm{mF}$

For the maximum output voltage from MPPT i.e. $V_{\text {in, } \max }=42 \mathrm{~V}$, $\mathrm{V}_{\mathrm{o}}=12.6 \mathrm{~V}$ all the above values were similarly calculated and can be summarized as given below:

$\mathrm{C}=55.8 \mathrm{mF}, \mathrm{L}=36.98 \mathrm{uH}$.

\section{PWM Converter -}

The DC output from the buck boost converter has to be converted to AC for outlets. Hence PWM inverter [11][12] is being used. This makes use of triangular waves as carrier signals and sine waves as modulating signals.

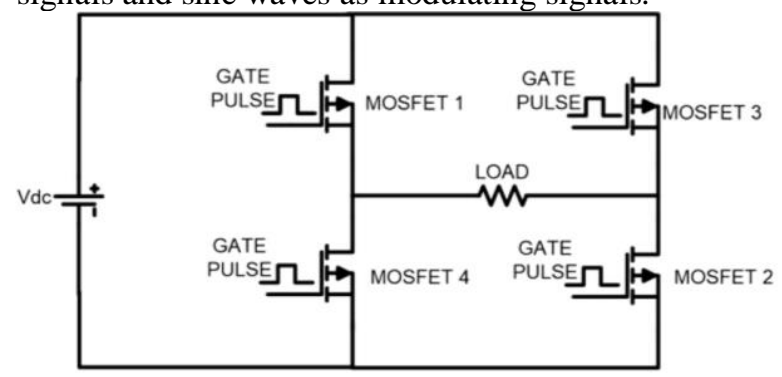

Fig. 6. PWM inverter with H-bridge topology

The design is as given below :

The Fourier series of the output voltage is given by, 


\section{International Journal of Engineering Applied Sciences and Technology, 2021 \\ Vol. 6, Issue 1, ISSN No. 2455-2143, Pages 325-330 \\ Published Online May 2021 in IJEAST (http://www.ijeast.com)}

$$
V_{o}(t)=\sum 4 V_{s} / n \square \sin (n \square / 2) \sin (n \square t)
$$

Here, $\square$ is the pulse width/pulse angle i.e. duration of ON pulse for one half cycle [Since the $\mathrm{V}_{\mathrm{o}}$ is symmetrical along $\mathrm{x}$-axis, even harmonics are absent]. To find out the rms value of the fundamental component consider $\mathrm{n}=1$

$$
V_{o}=4 V_{s} / \square \sin (\square / 2)
$$

By substituting $\mathrm{V}_{\mathrm{s}}=12.6 \mathrm{~V}$ and $\square=143.235^{\circ}$ in equation 18 , we get

$\mathrm{V}_{\mathrm{o}}=15.224 \mathrm{~V}$.

III. SIMULINK CIRCUIT MODEL AND RESULTS

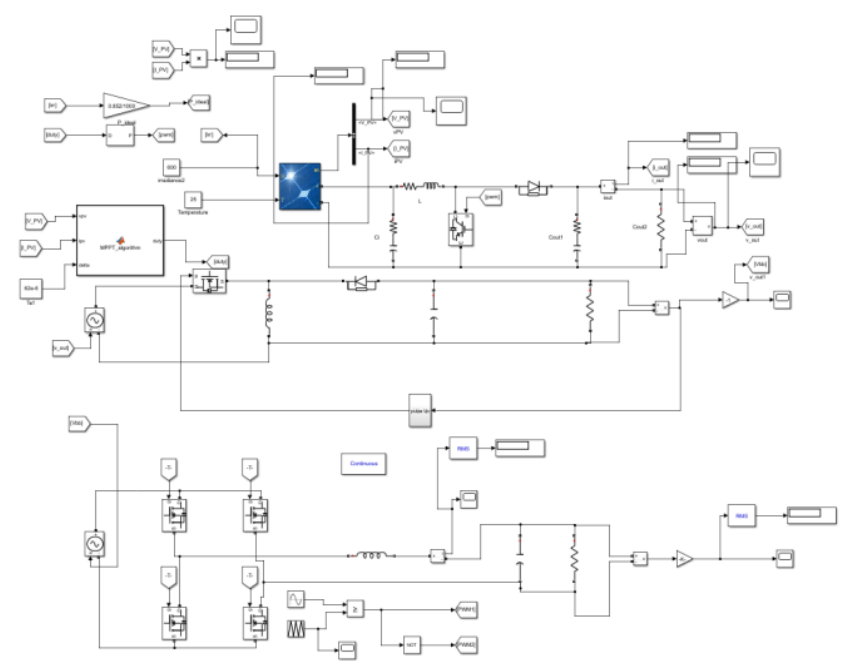

Fig. 7.The overall simulation diagram of Solar charge controller using $\mathrm{P} \& \mathrm{O}$ technique

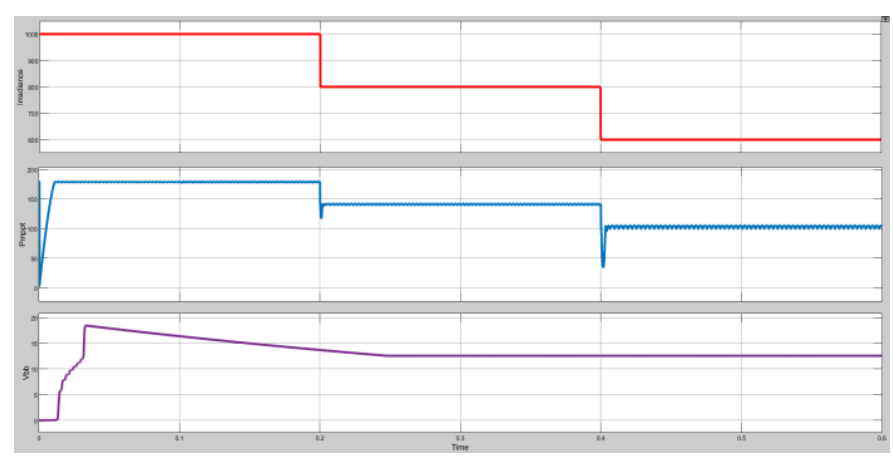

Fig. 8. Variation of MPPT power and dc output of buck-boost converter with the change in irradiance

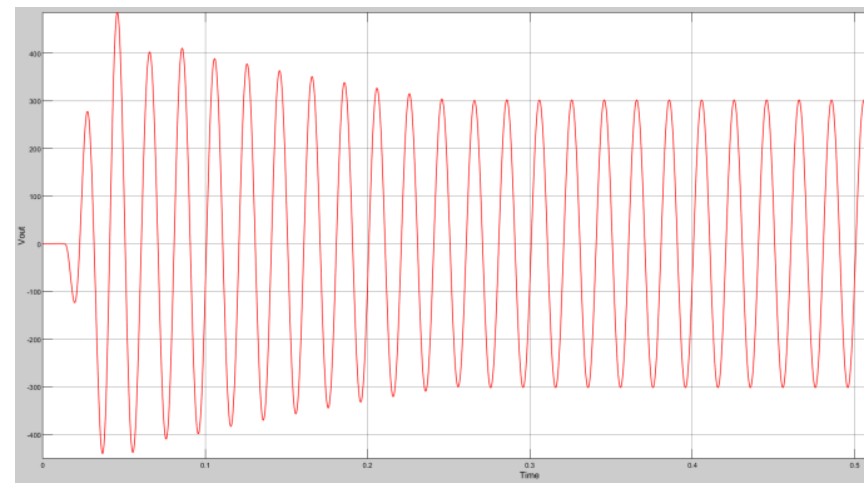

Fig. 9.The output voltage waveform of the combined circuit

Figure 7 shows the circuit model of the MPPT charge controller connected to the PV panel. The MPPT algorithm is coded in the Matlab Function block and with the changing irradiation (temperature being $25^{\circ} \mathrm{C}$ ), the maximum power from the PV panel also changed. The red line in the waveforms of figure 8 indicates $1000 \mathrm{~W} / \mathrm{m}^{2}, 800 \mathrm{~W} / \mathrm{m}^{2}$ and $600 \mathrm{~W} / \mathrm{m}^{2}$. The output power of the MPPT controller was found to be $178.01 \mathrm{~W}$, 142.3W and 105.1W for the above irradiations (as shown by the blue waveforms). The purple waveform indicates the constant dc voltage of around $12.6 \mathrm{~V}$ given by the Buck-Boost converter irrespective of the changing irradiances.

The sinusoidal waves in figure 9 indicate the output voltage of the combined system at $1000 \mathrm{w} / \mathrm{m}^{2}$ and the RMS value of the signal is $230 \mathrm{~V}$. An R-L load of $\mathrm{R}=240 \mathrm{ohm}, \mathrm{L}=0.5 \mathrm{uH}$ is used.



Fig. 10. Mathematical model of the charge controller with INC MPPT algorithm and RL load 


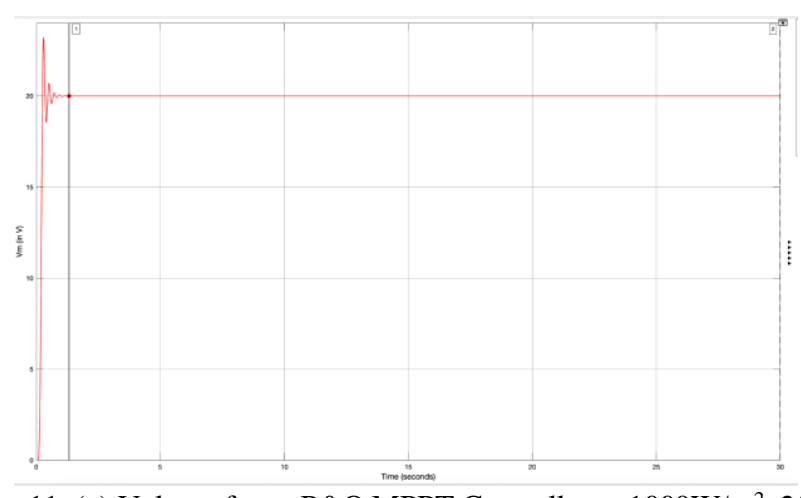

Fig. 11. (a) Voltage from P\&O MPPT Controller at $1000 \mathrm{~W} / \mathrm{m}^{2}, 25^{\circ} \mathrm{C}$ RL load

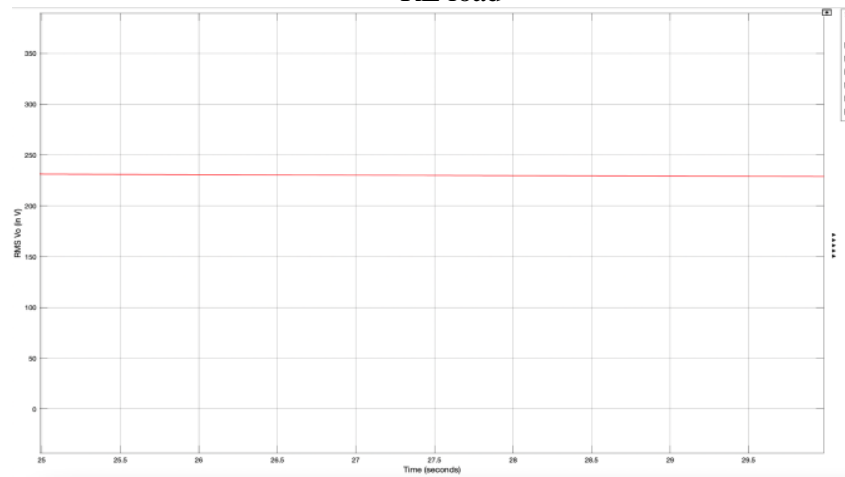

Fig. 11. (b) Voltage from INC MPPT controller at $1000 \mathrm{~W} / \mathrm{m}^{2}, 25^{\circ} \mathrm{C}$ and RL load

In figure 11 , although the voltage value is at $19.95 \mathrm{~V}$ in both graphs, graph (a) i.e. The $\mathrm{P} \& \mathrm{O}$ algorithm has a starting ripple and takes a few seconds to attain the steady state value. Hence the advantages of INC algorithm over P\&O are:

1) Starting ripple in voltage and current waveforms is reduced in INC

2) The voltage increment after comparison with the previous values happens significantly faster in this algorithm and hence the operating point at MPP can be attained quickly.

Table - 2 Outputs of two different loads for different irradiation from Mathematical model

\begin{tabular}{|l|c|l|}
\hline Solar irradiation & R load & \multicolumn{1}{c|}{ R-L load } \\
\hline Output at $1000 \mathrm{~W} / \mathrm{m}^{2}$ & $230 \mathrm{~V}(\mathrm{RMS})$ & $230.05 \mathrm{~V}, 0.958 \mathrm{~A}(\mathrm{RMS})$ \\
\hline Output at $800 \mathrm{~W} / \mathrm{m}^{2}$ & $230 \mathrm{~V}(\mathrm{RMS})$ & $230 \mathrm{~V}, 0.9588 \mathrm{~A}(\mathrm{RMS})$ \\
\hline Output at $600 \mathrm{~W} / \mathrm{m}^{2}$ & $230 \mathrm{~V}(\mathrm{RMS})$ & $230.2 \mathrm{~V}, 0.9583 \mathrm{~A}(\mathrm{RMS})$ \\
\hline
\end{tabular}

\section{CONCLUSION}

The energy harvesting and solar energy storage model has been successfully implemented using the MPPT charge controller in order to obtain a single phase $230 \mathrm{~V}, 50 \mathrm{~Hz}$ AC supply which can be used to power many domestic appliances. A complete robust set-up such as this as a whole is currently unlikely to have been simulated using simulink circuit and mathematical model. The $\mathrm{P} \& \mathrm{O}$ algorithm as well as INC algorithm has been successfully implemented and the integration of the individual working component has resulted in the production of the desired output, within appreciable range.

There are many solar MPPT charge controllers in the market with multi-voltage ranges of about $12 \mathrm{~V}$ to $24 \mathrm{~V}$ which can be connected with the batteries and solar panels. But most of them do not have interactive displays or in-built inverters and they have more scope to connect to the internet or remote databases.

\section{ACKNOWLEDGMENT}

The authors gratefully acknowledge Dr. Ravishankar B V, Principal, B.M.S.C.E. And Dr.C.Lakshminarayana, Hod, Department Of Electrical And Electronics Engineering, B.M.S.C.E. for their constant support during the course of this work.

\section{REFERENCE}

[1] Hiwale, Anil. Patil et al., "An Efficient MPPT Solar Charge Controller", July 2014, doi: 10.15662/ijareeie.2014.0307017.

[2] Praj K. Atri, P. S. Modi, Nikhil Shashikant Gujar, "Comparison of Different MPPT Control Strategies for Solar Charge Controller", 2020 International Conference on Power Electronics \& IoT Applications in Renewable Energy and its Control (PARC) GLA University, Mathura, UP, India. Feb 28$29,2020$.

[3] Amit Kumar Singh, Abhishek Kumar Agrawal, Simran Vohra, et al., "Solar charge controller", November 2017.

[4] Md. Rokonuzzaman, Md Hossam-E-Haider et al., "Design and Implementation of Maximum Power Point Tracking Solar Charge Controller", September 2016.

[5] Mihir Pathare, Vimith Shetty, Diptarka Datta et al., "Designing and Implementation of Maximum Power Point Tracking(MPPT) Solar Charge Controller”, January 2017.

[6] Tulika Majaw, Reeny Deka, Shristi Roy, Bikramjit Goswami, "Solar Charge Controllers using MPPT and PWM: A Review", ADBU Journal of Electrical and Electronics Engineering (AJEEE), February 2018.

[7] Markus Fjällid, "Design of a Real-Time Model of a Photovoltaic Panel", Royal Institute of Technology Stockholm, Sweden, June 2015. 
[8] Nguyen, X.H., Nguyen, M.P , "Mathematical modeling of photovoltaic cell/module/arrays with tags in Matlab/Simulink", April 2015.

[9] B.Chitti Babu, Tomas Cermak et al.,"Mathematical Modeling of PV Module with MPPT Algorithm”, June 2015.

[10] Xuelian Zhou, Qiang He, "Modeling and Simulation of Buck-Boost Converter with Voltage Feedback Control", MATEC Web of Conferences, January 2015, doi: 10.1051 /20153110006.

[11] Pankaj H Zope, Pravin G.Bhangale , S. R.Suralkar, "Design and Implementation of Carrier Based Sinusoidal PWM (Bipolar) Inverter”, December 2012.

[12] Nurul Farhana Abdul Hamid,“ Design and simulation of single phase inverter using SPWM unipolar technique”, First International Conference on Emerging Electrical Energy, October 2019. 